\title{
COMPARATIVE EFFICACY OF COMPOST, COMPOST TEA, POULTRY LITTER AND BAVISTIN IN CONTROLLING DISEASES OF CHILI
}

\author{
M. R. Hassan, I. Hossain*, M. R. Islam and M. A. R. Khokon \\ Department of Plant Pathology, Bangladesh Agricultural University \\ Mymensingh-2202, Bangladesh
}

\begin{abstract}
Compost, compost tea and poultry litter in comparison with Bavistin were evaluated for controlling diseases of chili. The experiments were conducted at Field Lab. and Eco-friendly Plant Disease Management Lab. of the Department of Plant Pathology, Bangladesh Agricultural University, Mymensingh, Bangladesh in 20112012 using eight different treatments following Randomized Complete Block Design with three replications. The treatments were (1) Compost tea $(1: 5 \mathrm{w} / \mathrm{v})$ as foliar spray, (2) Soil drenching with Compost tea $(1: 5 \mathrm{w} / \mathrm{v})$, (3) Soil drenching with poultry litter extract $(1: 5 \mathrm{w} / \mathrm{v})$, (4) Bavistin $(0.1 \%)$ as foliar spray, (5) Soil drenching with Bavistin (0.1\%), (6) Compost (10 t/ha) in soil application, (7) Poultry litter $(10 \mathrm{t} / \mathrm{ha})$ in soil application and (8) control. Minimum leaf curl incidence $(80.89 \%$ ) and severity grade (2) were recorded in plots under Compost tea @ 1:5 w/v as foliar spray, but severity and severity grade were maximum by $95.00 \%$ and 3, respectively under control plots. Minimum anthracnose infected plants $(16.67 \%)$ and infected fruit $(9.35 \%)$ were recorded in plots under Compost @ $10 \mathrm{t} /$ ha in soil application and soil drenching with poultry litter extract $(1.5 \mathrm{w} / \mathrm{v})$. The highest Cercospora leaf spot having severity rating grade 3.15 was recorded in field where compost tea was applied as soil drenching and lowest grade 1.07 was determined where Bavistin was applied as foliar spray. The fruit yield $(4.67 \mathrm{t} / \mathrm{ha})$ was found significantly higher in plots under compost tea as foliar spray and Bavistin as foliar spray which was $79.62 \%$ higher yield over control. Physical and chemical compositions of compost tea and poultry litter were determined.
\end{abstract}

Key Words: Compost, Compost tea, Poultry litter, Bavistin, Chili, Diseases, Management

\section{INTRODUCTION}

Chili is one of the most important spices in Bangladesh. The crop is known to suffer from as many as 83 different diseases of which 40 are caused by fungi (Anonymous, 1960; 1966; Rangaswami, 1979). Anthracnose, wilt, leaf curl and cercospora leaf spot are the major diseases in the country. Farmers spray chemicals for controlling these diseases. The indiscriminate use of chemicals cause environmental pollution and health hazards. As an alternate means biological agents are being used for combating the disease. Biological control is environmentally safe, durable and cost effective alternatives to chemical

*Corresponding author (Email: dhossain69@gmail.com) 
compounds (Paplomatas, 2005). Living microorganisms such as bacteria, viruses or fungi are employed in biological control either as antagonists, parasites or predators (Kwok et al. 1987) composts are known to suppress plant diseases through a combination of physiochemical and biological characteristics (Rou, 2003). Physiochemical characteristics include any physical or chemical aspects of composts that reduce disease severity by directly or indirectly affecting the pathogen or host capacity for growth. These aspects include nutrient level, organic matter, moisture, $\mathrm{pH}$, and other factors. Compost tea has been defined simply as liquid extract from compost material that may contain organic and inorganic soluble nutrients, and a large number of organisms including bacteria, fungi protozoa and nematodes (Kone, 2010). It is emerging as a crop protection tool and has been using for organic agriculture for a number of reason viz. it contains microorganisms which can reduce incidence of foliar and/or soil-borne diseases, nutrients in a readily available form which rapidly benefit plant growth through direct contribution to plant nutrition and is easily integrated into existing plant fertility and disease control programs due to its easy application via existing irrigation or spray equipment, or as a soil drench.

Chicken litter has long been used as a soil amendment to provide nutrients for plant growth, increase organic matter in the soil improve microbial populations in the soil, and to control pathogens (Riegel and Noe, 2000). Keeping all the above mentioned facts, the present study was undertaken to assess the effect of compost tea and poultry litter on the incidence and severity of diseases of chilli in the field.

\section{MATERIALS AND METHODS}

The experiment was conducted at the Field Laboratory and Eco-friendly Plant Disease Management Laboratory of Department of Plant Pathology, Bangladesh Agricultural University, Mymensingh, Bangladesh in 2011-1012. The soil of the experimental plot was fine sandy loam in texture belonging to Old Brahmaputra Floodplain (FAO, 1999). The land was ploughed with a power tiller and exposed to sunlight for 7days. Then the land was ploughed and cross-ploughed until the soil had a good tilt followed by laddering. Weeds and rubbish were removed. The experiment was laid out in Randomized Complete Block Design (RCBD) with three replications. The treatments were $T_{1}=$ Control, $T_{2}=$ Compost tea as foliar spray $(1: 5 \mathrm{w} / \mathrm{v}), \mathrm{T}_{3}=$ Compost tea $(1: 5 \mathrm{w} / \mathrm{v})$ as soil drenching, $\mathrm{T}_{4}=$ Poultry litter extract $(1: 5 \mathrm{w} / \mathrm{v})$ as soil drenching, $\mathrm{T}_{5}=$ Bavistin $(0.1 \%)$ as foliar spray, $\mathrm{T}_{6}=$ Bavistin $(0.1 \%)$ as soil drenching, $\mathrm{T}_{7}=$ Compost $(10 \mathrm{t} / \mathrm{ha})$ in soil application, $\mathrm{T}_{8}=$ Poultry litter in soil application $(10 \mathrm{t} / \mathrm{ha})$. Compost tea was prepared by mixing compost with tap water at a ratio of $1: 5(\mathrm{w} / \mathrm{v})$ followed by fermentation for a week at $25^{\circ} \mathrm{C}$ in Net house, where the mixture was stirred once in every day. After fermentation the mixture was filtered through cheese cloth and the prepared compost tea i.e. extract was ready for application. The same procedure was used for preparation of poultry litter extract.

Seeds of local chili variety Bindu were sown in seed bed. The seedlings of 30 days old were uprooted from the seedbed and transplanted in January, 2011 in the experimental plots. The distances between the plants as well as between rows were $50 \mathrm{~cm}$ and $50 \mathrm{~cm}$, respectively. A sufficient irrigation was given just after transplantation with the help of a bucket sprinkler. 
Then the experimental plot soil was drenched by the prepared compost tea and poultry litter extract with sprayer @ 1 liter per $1.5 \mathrm{~m}^{2}$ area. First and second soil drenching were done at 45 and 60 days after transplanting (DAT), respectively, while third was done at 75 DAT. Both extracts of compost tea and poultry litter were sprayed at 15 days interval to the assigned plots @ $50 \mathrm{~L} / \mathrm{ha}$. The first, second and third sprays were given 60, 75 and 90 DAT.

The chilli plants in plots were examined periodically. Leaf curl infection was identified following the key outlined by Scott and Schuster (1991). The severity of leaf curl was recorded at 70 DAT using scale given by Enikuomehin et al. (2002). Cercospora leaf spot was also identified by following the keys outlined by Enikuomehin et al. (2002). In addition, anthracnose of chilli was characterized by following the keys of Isaac (1992). Physical and chemical characteristics of compost tea and poultry litter extract were analyzed in the laboratory of Division of Soil Science of Bangladesh Agricultural Research Institute (BARI), Joydebpur, Gazipur, Bangladesh.

The collected data on different diseases were analyzed statistically using analysis of variance to find out the variations resulting from experimental treatments and the treatment means were compared by DMRT (Duncan's Multiple Range Test).

\section{RESULTS AND DISCUSSION}

Though the height of the plants varied from 61.05 to $74.72 \mathrm{~cm}$ and branching varied from 5 8 , but no significant variation under different treatments in respect of plant height and branching of chilli plants was recorded. That indicating application of compost, compost tea and poultry litter extract does not exert any harmful effect on plant growth, rather poultry litter resulted higher growth of cotton (Riegel and Noe, 2000) plant over control. Use of poultry litter resulted higher plant growth that might be due to addition of organic matter to soil which supply nutrient to the crop.

The incidence of leaf curl disease ranged from 80.89 to $95.00 \%$, where as leaf curl disease rating scale varied from 2 to 3 under different treatments (Table 1). Application of compost, compost tea, poultry litter and extract of poultry litter resulted reduction of incidence of leaf curl disease over control. The variation of incidence of leaf curl has also been supported by Chandrasekaran (2005) and De et al. (2005). The incidence of anthracnose under different treatments varied significantly from one treatment to another (Table 1). Anthracnose infected plant ranged from 16.67 to $61.11 \%$. The lowest infection was found in case of compost in soil application which is statistically similar to all other treatments except control. Anthracnose incidence was significantly highest (61.11\%) in control. In case of anthracnose infected fruit, lowest number of diseased fruit was recorded in case of using poultry litter extract $(9.35 \%)$ and highest $(15.25 \%)$ under control. Compost application resulted highest reduction (44.44\%) of anthracnose. According to Abbasi et al. (2002) incidence of anthracnose fruit rot was reduced in tomato plots that amended with compost. The highest Cercospora leaf spot having severity rating grade 3.15 was recorded in field where Compost tea was applied as soil drenching and lowest grade 1.07 was determined where Bavistin was applied as foliar spray. 
Table 1. Effect of compost tea and poultry litter in comparison with bavistin in controlling leaf curl, anthracnose and Cercospora leaf spot of chili

\begin{tabular}{|c|c|c|c|c|c|}
\hline Treatments & \begin{tabular}{|c|} 
Incidence \\
of leaf \\
curl (\%)
\end{tabular} & $\begin{array}{l}\text { Leaf curl } \\
\text { rating } \\
\text { scale } \\
(1-5)^{*}\end{array}$ & \begin{tabular}{|c|} 
Anthracnose \\
infected plant \\
$(\%)$
\end{tabular} & $\begin{array}{l}\text { Anthracnose } \\
\text { infected fruit } \\
(\%)\end{array}$ & $\begin{array}{c}\text { Severity of } \\
\text { Cercospora leaf } \\
\text { spot (Rating } \\
\text { grade } 1-7)^{* *}\end{array}$ \\
\hline Control & 95 & 3 & $61.11^{\mathrm{a}}$ & $18.25^{b}$ & 1.93 \\
\hline $\begin{array}{l}\text { Compost tea }(1: 5 \mathrm{w} / \mathrm{v}) \text { as } \\
\text { foliar spray }\end{array}$ & 80.89 & 2 & $38.89 \mathrm{ab}$ & $\begin{array}{l}17.92^{\mathrm{b}} \\
(22.22)\end{array}$ & 3.30 \\
\hline $\begin{array}{l}\text { Compost tea }(1: 5 \mathrm{w} / \mathrm{v}) \text { as soil } \\
\text { drenching }\end{array}$ & 88.89 & 2 & $38.89 \mathrm{ab}$ & $\begin{array}{l}15.88^{b} \\
(22.22)\end{array}$ & 3.15 \\
\hline $\begin{array}{l}\text { Poultry litter extract }(1: 5 \mathrm{w} / \mathrm{v}) \\
\text { as soil drenching }\end{array}$ & 93.33 & 2 & $27.78^{b}$ & $\begin{array}{c}9.35^{\mathrm{b}} \\
(33.33)\end{array}$ & 1.70 \\
\hline Bavistin $(0.1 \%)$ as foliar spray & 93.33 & 2 & $22.22^{b}$ & $\begin{array}{l}20.64^{\mathrm{ab}} \\
(38.89)\end{array}$ & 1.07 \\
\hline Bavistin $(0.1 \%)$ soil drenching & 89.78 & 2 & $22.22^{b}$ & $\begin{array}{l}30.84^{\mathrm{a}} \\
(38.89)\end{array}$ & 1.43 \\
\hline $\begin{array}{l}\text { Compost }(10 \mathrm{t} / \mathrm{ha}) \text { in soil } \\
\text { application }\end{array}$ & 87.78 & 2 & $16.67 \mathrm{~b}$ & $\begin{array}{l}15.71^{\mathrm{b}} \\
(44.44)\end{array}$ & 1.67 \\
\hline $\begin{array}{l}\text { Poultry litter }(10 t / h a) \text { in soil } \\
\text { application }\end{array}$ & 95.00 & 2 & $22.22^{b}$ & $\begin{array}{l}11.41^{\mathrm{b}} \\
(38.89)\end{array}$ & 1.83 \\
\hline LSD $(P \geq 0.05)$ & & & 25.18 & 10.28 & \\
\hline
\end{tabular}

* Scale of Scott and Schuster (1991), ** Rating grade of Enikuomehin et al. (2002), Data in parentheses indicate $(\%)$ reduction over control

The highest fruit yield (4.67t/ha) was obtained in Compost tea as foliar spray and Bavistin foliar spray followed by Compost soil application, while the lowest yield $(2.2 \mathrm{t} / \mathrm{h})$ was obtained in by Poultry litter extract as soil drenching which was statistically similar to control $(2.6 \mathrm{t} / \mathrm{h})$ as shown in Table 2. Highest yield increase $(79.62 \%)$ was recorded in by Compost tea as foliar spray and Bavistin as foliar spray, while the lowest yield increase $15.38 \%$ was recorded in Bavistin as soil drenching. In vitro study showed that bacteria present in compost tea and poultry litter extract that resulted profound effect in inhibiting the growth of c. capsici. Physical and chemical characteristics of compost tea and poultry litter were almost similar as shown in Table 3. However, compost tea as foliar spray resulted profound effect in increasing yield of chilli, which is almost similar to chemical Bavistin spray, The findings of the present study supported by Islam et al. (2013), where they got organic management as an alternative approach to control diseases of brinjal, potato and tomato. Under the present study compost tea as well as bavistin as foliar spray resulted the highest fruit yield of chili which is $79.62 \%$ increase over untreated (control). Therefore, it may be pointed out that organic way of chili disease management i.e. use of compost tea can be encouraged rather than use of chemicals, like bavistin. This will help to avoid environmental pollution of using chemicals. 
Table 2. Effect of compost tea and poultry litter in comparison with bavistin on yield of chili

\begin{tabular}{l|c|c}
\hline \multicolumn{1}{c|}{ Treatments } & Yield & $\begin{array}{c}\text { Yield increase }(+) \text { or decrease }(-) \text { over } \\
\text { control }(\%)\end{array}$ \\
\cline { 2 - 2 } & t/ha & \\
\hline Control & $2.60^{\mathrm{b}}$ & +79.62 \\
Compost tea $(1: 5 \mathrm{w} / \mathrm{v})$ as foliar spray & $4.67^{\mathrm{a}}$ & +25.38 \\
Compost tea $(1: 5 \mathrm{w} / \mathrm{v})$ as soil drenching & $3.26^{\mathrm{ab}}$ & -15.38 \\
Poultry litter extract $(1: 5 \mathrm{w} / \mathrm{v})$ as soil drenching & $2.20^{\mathrm{b}}$ & +79.62 \\
Bavistin $(0.1 \%)$ as foliar spray & $4.67^{\mathrm{a}}$ & +15.38 \\
Bavistin $(0.1 \%)$ soil drenching & $3.00^{\mathrm{ab}}$ & +74.23 \\
Compost $(10 \mathrm{t} / \mathrm{ha})$ in soil application & $4.53^{\mathrm{a}}$ & +35.00 \\
Poultry litter $(10 \mathrm{t} / \mathrm{ha})$ in soil application & $3.51^{\mathrm{ab}}$ & \\
\hline LSD (P $\geq 0.05)$ & 1.701 &
\end{tabular}

Table 3. Physical and chemical characteristics of compost tea and poultry litter

\begin{tabular}{|c|c|c|c|}
\hline \multirow[t]{2}{*}{ SL. No. } & \multirow[t]{2}{*}{ Specification } & \multicolumn{2}{|c|}{ Test results } \\
\hline & & Compost tea & Poultry litter \\
\hline 1 & Physical status & Liquid & Liquid \\
\hline 2 & Colour & Black & Black \\
\hline 3 & Odour & Slight odour & Slight odour \\
\hline 4 & $\mathrm{pH}$ & 6.80 & 7.30 \\
\hline 5 & $\mathrm{OC}(\%)$ & Trace & Trace \\
\hline 6 & Total N (\%) & 0.14 & 0.14 \\
\hline 7 & Ca (\%) & 0.069 & 0.075 \\
\hline 8 & $\operatorname{Mg}(\%)$ & 0.021 & 0.022 \\
\hline 9 & $\mathrm{Fe}(\%)$ & 0.48 & 0.55 \\
\hline 10 & $\operatorname{Mn}(\%)$ & 0.28 & 0.32 \\
\hline 11 & B (\%) & 0.026 & 0.027 \\
\hline 12 & P (\%) & 1.20 & 1.40 \\
\hline 13 & K (\%) & 0.053 & 0.146 \\
\hline 14 & $\mathrm{~S}(\%)$ & 0.50 & 0.60 \\
\hline 15 & $\mathrm{Cu}(\%)$ & 0.005 & 0.008 \\
\hline 16 & $\mathrm{Zn}(\%)$ & 0.026 & 0.054 \\
\hline 17 & $\mathrm{~Pb}(\mathrm{ppm})$ & Trace & Trace \\
\hline 18 & $\mathrm{Cd}(\mathrm{ppm})$ & Trace & Trace \\
\hline 19 & $\mathrm{Cr}(\mathrm{ppm})$ & Trace & Trace \\
\hline 20 & $\mathrm{Ni}(\mathrm{ppm})$ & Trace & Trace \\
\hline
\end{tabular}




\section{REFERENCES}

Abbasi, P. A., Aldahmani, J., Sahin, F., Hoitink, H. A. J. and Miller, S. A. 2002. Effect of compost amendments on disease severity and yield of tomato in conventional and organic production systems. Department of Plant Pathology, The Ohio State University, Ohio Agricultural Research and Development Center, Wooster, OH 44691, USA.

Anonymous. 1960. Index of plant diseases in the United States. Agriculture Head Book No. 165. U.S. Department of Agriculture. p. 531.

Anonymous. 1966. Index of plant virus diseases. Agriculture Head Book No. 307 U.S. Department of Agriculture. p. 446.

Chandrasekaran, M. 2005. Symptomatology of chilli leaf curl. J. Ecotoxico. Environ. Monitoring 15(4): 377-380.

De, B. K, Saha, A. K. and Nath, P. S. 2005. Leaf curl virus disease incidence in chilli in the plains of West Bengal. Environment and Ecology, 23(Special 2): 261-263.

Enikuomehin, H. Y., Liu, C.Y., Wang, Y. 2002. A study on symptoms of Cercospora leaf spot disease of different vegetables. China Vegetables, (6): 26-28.

FAO (Food and Agriculture Organization) 1999, Land Resources Appraisal of Bangladesh for Agricultural Development. Report 2. pp. 211-212.

Islam, M. R., Mondal, C., Hossain, I. and Meah, M. B. 2013. Compost tea as soil drench and alternative approach to control bacterial wilt in brinjal. Archives of Phytopathology and Plant Protection. http:dx.doi.org/10.1080/03235408.2013.847654.

Islam, M. R., Mondal, C., Hossain, I. and Meah, M. B. 2013. Compost Tea and Poultry Litter Extract: Alternative Organic Management Approaches for Stem Canker of Potato Caused by Rhizoctonia solani. J. Agricultural Sci., 5(10): 261-272.

Islam, M. R., Mondal, C., Hossain, I. and Meah, M. B. 2013. Organic Management: An Alternative to Control Late Blight of Potato and Tomato Caused by Phytophthora infestans. International J. of Theoretical \& Applied Science, 5(2): 32-42(2013).

Kone, M. 2010. Suppressive effect of non-aerated compost teas on foliar fungal pathogens of tomato. Biological control, 52(2):167 - 173.

Kwok, O. C. H., Faty, P. C., Hoitink, H. A. J. and Kuter, G. A. 1987. Interactions between bacteria and Trichoderma harnatum in suppression of Rhizoctonia damping off in barkcompostmedia. Phytopathol., 77(8): 1206-1212.

Paplomatas, J. 2005. Evaluation of compost amendments for suppressiveness against Verticillium wilt of eggplant and study of mode of action using a novel Arabidopsis pathosystem. European J. Plant Pathol., 112(2): 183-189.

Rangaswami, G. 1979. Diseases of crop plants in India, private Ltd., India. 520 pp.

Riegel, C. and Noe, J. P. 2000. Chicken litter soil amendment effects on soil borne nematode Meloidogyne incognita on cotton. Plant Disease, 84: 1275-1281.

Rou, P. V. 2003. Suppression of tomato early blight by spraying of animal manure based compost water extracts. Suppression of tomato early blight by spraying of animal manure based compost water extracts. Annals of the Srilanka Department of Agriculture, 5: 175-191.

Scott, J. W. and Schuster, D. J. 1991. Screening accessions for resistance to the Florida tomato geminivirus. TGC Rept., 41: 48-50. 